\title{
プリント基板検査システムに関する研究*
}

\author{
里 見 忠 篤*1, 野口祐 智*2
}

\section{Study of Printed Circuit Board's Inspecting System}

\author{
Tadaatsu SATOMI*3 and Masanori NOGUCHI \\ ${ }^{* 3}$ Graduate School of Science and Engineering, Tokyo Denki University, \\ Ishizaka, Hatoyama-machi, Hiki-gun, Saitama, 350-0394 Japan
}

\begin{abstract}
The digital technology contributes to the reduction in size of equipment such as mobile phones and personal computers. Accordingly, the advancement in the production of printed wiring boards is also remarkable. Presently, the inspection of printed wiring boards includes the conductivity, the capacitance, the appearance inspections, and so forth. There are problems of the conduction defects, the effect of the stray capacitance and the mistaken image in these inspections. In order to resolve these problems, in our research a pin probe with a dielectric substance is produced, a serial resonance circuit is constructed in a manner that the spacing between the electrodes of the probe and those of the wiring board is regarded as a condenser, and an inspection system is developed which can determine the connection, insulation, short-circuiting and disconnection by measuring the magnitude of resonance current value. Usability of this scheme is verified after the check test has been conducted using a wiring board such as BGA and PWB.
\end{abstract}

Key Words: Printed Wiring Board, Printed Circuit Board, Ball Grid Array, Tester, Inspection, Capacitance, Condactance

\section{1. 粕 言}

近年, 携帯電話に代表されるように, 製品は小型化・ 高速化の傾向にある. その燘りを受けて機器の機能を 保障するために高度な電子制御技術が必要になってき ている. その傾向に伴い, 主要部品のひとつであるプ リント配線板 (PWB : Printed Wiring Board) の高密度化・ 多層化が進み，高度な電子制御が行われている。 その ためPWB の信頼性は年々厳しくなり，不良率は $0.01 \%$ 以下と大変厳しいものとなっている. 現在, 主流とな っている検査方法は 1)導通検查, 2)外観検査が挙げら れる. 導通検査は PWB の電極群の中より 2 箇所の電 極に電圧を印加し, その際の通電状況によって正常・ 短絡・断線の判定を行っている. 検査装置は PWB を プローブユニットで上下から挟み込む方式と，フライ ングプローバ方式がある. 導通検査は判定方法が分り 易いが, 久点としてはプローブ先端が電極に傷をつけ てしまうことがあり，端子表面の絶縁皮膜層の影響で 接触不良が生じる畏れもある. 外観検查は CCD（可視 光) やX 線をPWBに照射した際に得られた画像をコ

\footnotetext{
* 原稿受付 2007 年 1 月 10 日.

*1 正員, 東京電機大学大学院理工学研究科(画350-0394 埼玉 県比企郡鳩山町石坂)

*2 学生員, 東京電機大学大学院理工学研究科.

E-mail : noguchi @ satomilab.n.dendai.ac.jp
}

ンピュータによって良品の画像と比較することで, 配 線上に生じている久損や接触状況を調べる. この方法 の利点は画像処理のため検査を迅速に行うことができ, 且つ画像の差し替えで検查パターンの変更が容易にで きることであるが, 電気的特性は未確認の状態になっ てしまうので最終的な検查方法とは言い難い. 本研究では, PWB の断線・短絡検査精度の向上を狙い, PWB の電極間の静電容量を調べる方式に着目した. 具 体的には，導通検查で用いられていた金属製のプロー ブの先端に誘電体を取り付けることによりプローブと PWB の電極間をコンデンサの並行平板モデルに見立 て, 2 電極間に生じる静電容量を直列共振回路の構成 要素とし, その共振電流の変化を調べる方法て配線の 断線・短絡状況を判断する. この方法により, 現在主 流となっている通電型検查装置のいくつかの問題点を 解決することができた.

\section{2. システム構成}

本研究では, プローブとプリント配線板の電極間に 生じる静電容量に着目し, 検査対象回路毎に直列共振 回路を構成させ，その共振特性を調べることで配線の 断線・短絡を見極めている.このシステムを実現させ るために $2 つ の$ 重要な技術開発が行われた。 その1は スプリングプローブ先端に誘電体を装着した容量型の 
プローブを製作した，その 2 はUSB-コンピュータとア ナログマルチプレックサ(A.M.P.: Analog. Multi-Plexer.) を用いて，高速スイープおよび高速回路切替を可能に した. 図 1 は検査装置構成を示寸。

$\mathrm{PC}($ パーソナルコンピュータ) : PC は本研究で開発さ れた検査プログラムの保存とその運用を行い，検査に 必要な機能を得るためにUSB-コンピュータの監視・制 御を行っている. 主な作用プログラムとして, (1)スイ 一プ信号を発振させるためのプログラム. (2)検査回路 の選択, 切替のプログラム. (3)データの取り込み, 表 示するプログラムなどがある.

USB-コンピュータ : USB-コンピュータは H8-3048

(MPU: Micro processor unit) , RAM, USB1.1インターフ エイスから構成されており, スイープ信号の発振は USB-コンピュタ内の RAM に保存された H8 専用 mot ファイルを起動させ, ITU(Integrated Timer Unit)を用い てパルスの発振するタイミングを決定することにより 行われている. 信号をスイープさせるためにはタイマ 一設定を時間経過で変化させることにより行われる. また H8内の A/D ポートにより出力電圧を検出し, 24Bit $\mathrm{DI} / \mathrm{DO}$ (デジタル入出力)を用いて回路切替信号を出力 している.

切替回路 : 高速切替を実現するためにアナログマル チプレックサ(A.M.P.: 74HC4051) を用いて回線の切替 を行っている: この A.M.P.は8チャンネルの切替IC の ため, 全点検査を行うためには並列に配置し, 動作し ている A.M.P.を選択するためのデコーダとして 74HC138を使用している. これにより，1つの共通電 極に対して複数の端子を得ることができる. 図 2 は切 替回路を示す.

検查部 : プローブが移動するタイプでは対応しきれ ない多点電極基板の検査は上下からの挟み込み型が用 いられている. 本装置ではPWB の電極に合わせたプロ 一ブ固定治具 (図 3 の Insulator: 樹脂系の絶縁体) を使 用寸ることで誘電体プローブの正確な位置決めを可能 にしている.

誘電体付プローブ : 図4に示すように本研究では圧 電用誘電体のセラミック $(0.4 \mathrm{~mm}$ 角) に液体はんだを 用いてスプリングプローブに接着している.

プリント配線板を検查部にセットし，上下からプロ ーブユニットで挟み込むことで，プローブが電極に接 触する. PC 上でプログラムを起動させると USB-コン ピュタとの通信が開始され，プログラムより $\mathrm{DI} / \mathrm{DO}$ を 介して Switching Unitにチャンネル切替信号が送信され， 自動的に検查経路が選択される.この検査経路は図 5 に示した.

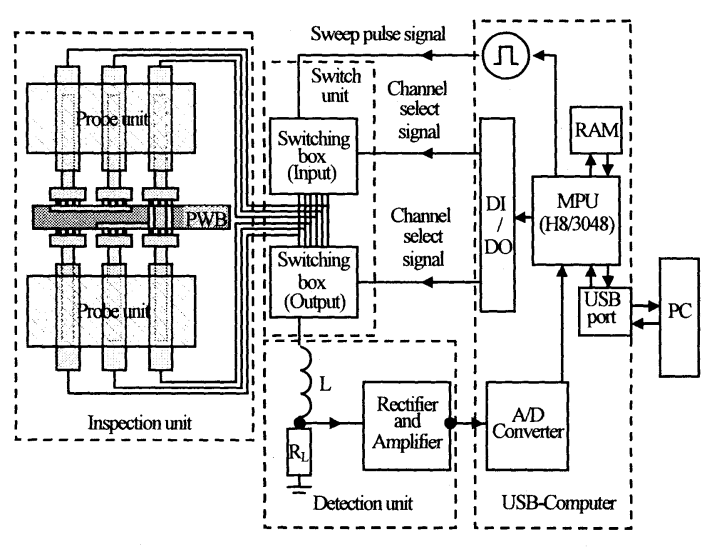

Fig.1 Inspection system

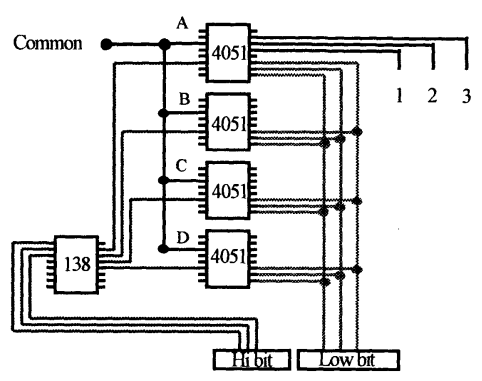

Fig.2 Switching circuit model

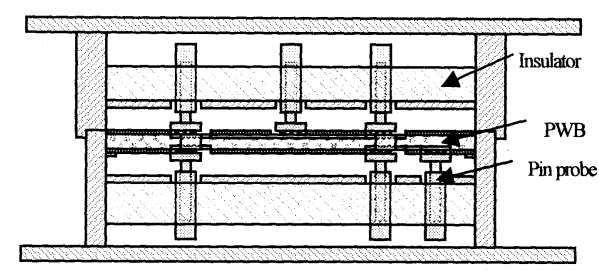

Fig.3 Detecting probe unit

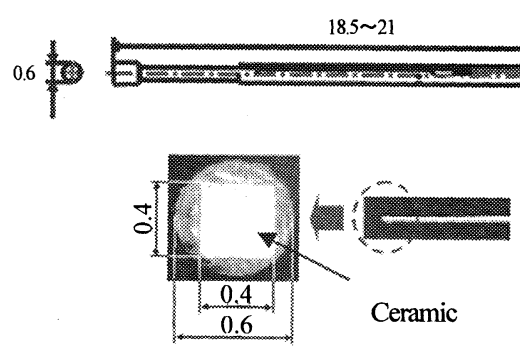

Fig.4 Probe end with ceramic 


\section{3. 検査システム}

$3 \cdot 1$ 本検査装置のシステム概要＼cjkstart本システムは PC 内に設定された主プログラムにより実行されてい る. 主プログラムは検査項目及び検查電極のデータ心゙ 一ス・検査回路の設定・制御・測定・判定用の各プロ グラムから構成されている，具体的には検查電極の総 数(NIE: Number of inspection electrodes ), 共振現象の判 断基準となる闇値電圧(Vt: Threshold voltage)を初期設定 する．検查項目のデータベースには検查名及び検查電 極番号(IEN: Inspection electrode number)，チャンネル切 替信号(CSS: Channel select signal)及び理論共振特性符号 (TRP: Theoretical resonance phenomenon)を記憶させてい る.この理論特性より使用されるスイープ信号周波数 範囲及び閾值電圧を設定することができる. 主プログ ラムを始動すると自動的にIENに”l”が選択され，IEN ${ }_{1}$ の $\mathrm{CSS}_{1}, \mathrm{CSS}_{2}$ が USB コンピュータにより切替回路に 入力され検査回路が選択される. スイープ信号が回路 に印加されると共振回路内に共振電流が生じ，その際 負荷抵抗両端に発生する出力電圧を測定する. USB コ ンピュータ内の基準周波数を基に調整されたスイープ 信号周波数と出力電圧のデジタル值を主プログラムに 転送し，プログラム内で周波数及び出力電圧值に換算 し共振曲線の描画・共振現象の有無の判定に使用する. 共振現象の有無は間值電圧を超えた（十符号: ”1”) か 否か (一符号: "0") によって判断する. 共振特性の実 測值(ARP: Actual resonance phenomenon)は符号化されて 記憶される．設計上の配線符号（TRP）と実測の共振 特性による配線符号（ATP）を比較し，同符号であれ ば正常な配線と判定し，異符号の場合は配線の短絡も しくは断線といった異常があることを示している. IEN ${ }_{1}$ の検査が正常に終了すると IENに”1”が加算され IEN ${ }_{2}$ の值が検査に適応される. 順次 IEN を加算し IEN が NIE と同数となった時点で検査は終了する. 図 7 は検 查プロセスを表す。

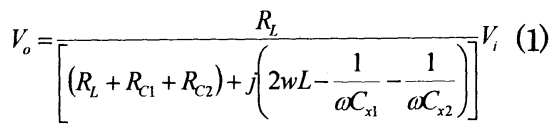

$V_{o}$ : Output voltage $V_{i}$ : Input voltage

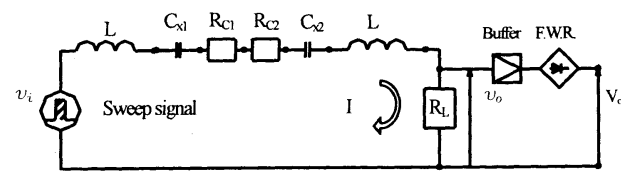

$\mathrm{L}$ : Inductance, $\mathrm{Cx1}, \mathrm{Cx} 2$ : Probe's capacitance, $\mathrm{R}_{\mathrm{cl}}, \mathrm{R}_{\mathrm{c} 2}$ : Probe's resistance $\mathrm{R}_{\mathrm{L}}$ : Load resistance, Buffer: Amplifier, F.W.R: Full Wave Rectification

Fig.5 Equivalent circuit

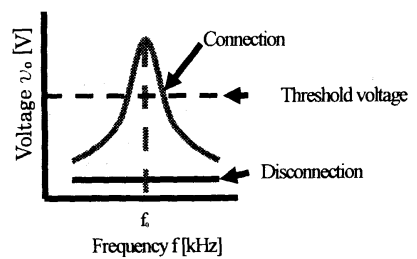

Fig.6 Resonance curves

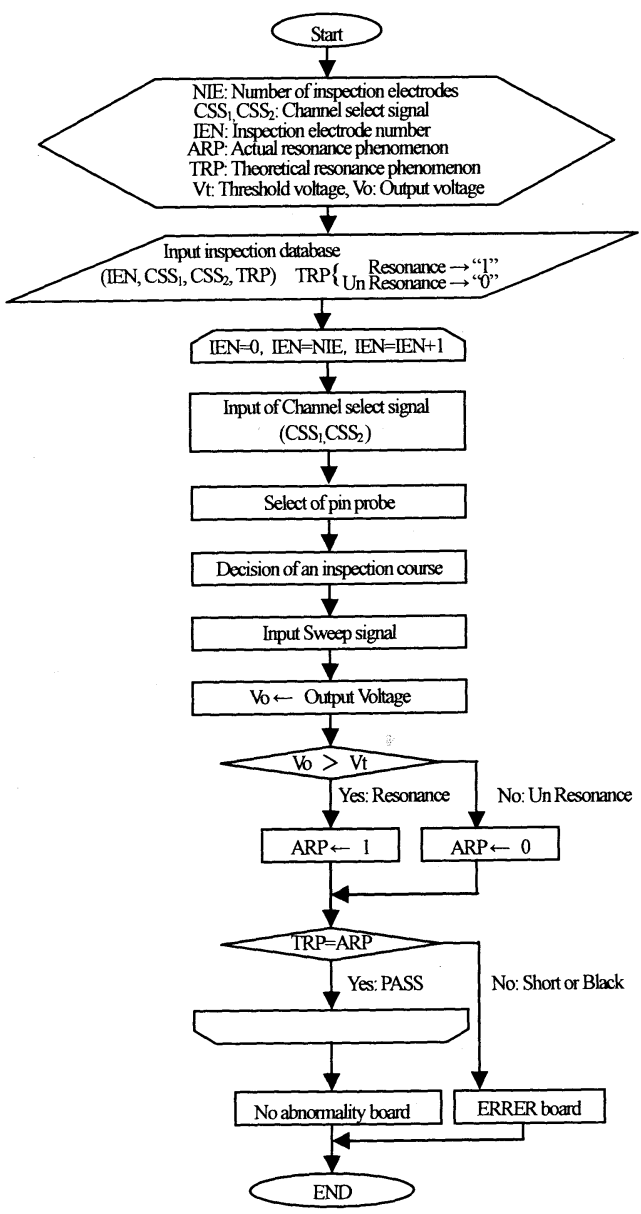

Fig.7 Inspection system 
$3 \cdot 2$ 断線検查設計上結線されているべき回路 にエッチング等によって, 意図せぬ箇所にピンホール, 欠け，断線といった欠陥が生じていないかを検査する ものである. 設計上 2 電極間が結線されている場合に は電気的に繋がるため検査回路は閉回路となり，スイ 一プ信号を発振したときに共振周波数近傍において共 振電流は増加し, 負荷抵抗両端の出力電玨が上昇する. しかし, 異常 (断線) 時は 2 電極間が電気的に切り離 されるため検査回路は開回路となり共振現象は起きな い. したがって発振したときに負荷抵抗の両端には出 力電圧が生じない. 図 8 は断線検查例を示寸.この場 合, 設計上では 1 番と 2 番は結線され, それ以外のピ ンは絶縁状態となっている. 何らかの原因により 1 番 と 2 番の配線が断線してしまうと端子間に電流が流れ ず, 負荷抵抗両端に電圧が生じない.

$3 \cdot 3$ 短絡検査 設計上結線されていない回路が パターン転写等によって, 意図せぬ箇所に短絡が生じ ていないかを検査するものである. 設計上 2 電極間が 絶縁されている場合は電気的に慗がらないため検査回 路は開回路となり, スイープ信号を発振したときに負 荷抵抗両端の出力電圧が生じない. しかし, 異常（短 絡）時は 2 電極間が電気的に熬がってしまうので検查 回路は閉回路となり，スイープ信号を発振したときに 共振周波数近傍において共振電流は增加し, 負荷抵抗 雨端の出力電圧が上昇する. 図9は断線検査例を示す. この場合, 設計上では 4 番はそれ以外のピンとは結線 されていないが，何らかの原因により 4 番と 1 番の配 線が短絡してしまうと端子間に電流が流れ, 負荷抵抗 両端に電圧が生じる.

3.4 スルーホール検查 図 10 はスルーホール検 查例を示す. スルーホールは 3 番と 6 番のようにプリ ント配線板の表・裹を貫く方向にめっき処理され，電 気的に通電することが可能となっている. 基本的には スルーホールは結線されているが, 内部のコーナーラ ック（部分欠損）やバレルクラック（完全断線）とい った欠陥を検出する必要がある. そのためにスルーホ 一ルに対して断線検査が必要となる.

\section{4. 実鈳}

本研究では2種類の配線板(BGA, PWB)を検查対象と している. BGA(Ball Grid Array)は Pattern 面と Ball 面を 有する. Pattern 面側はIC の取り付け面であり，端子は 小さく線間ピッチも狭くなっている．また, Ball 面側 は通常の配線基板に半田付けされるため端子も大きく 線間ピッチも広くなっている. BGA の構造は Pattern 面側と Ball 面側が 1 対 1 て配線されているので, 検査
項目は断線検查, 短絡検查である. PWB は両面配線板 *を検查対象とした. 配線板の電極には直径 $1.26[\mathrm{~mm}]$ の金属層に直径 $0.63[\mathrm{~mm}]$ の貫通孔（スルーホール）が 形成されている.PWBの配線は，スルーホールを含む 立体配線（両面配線）となるため設計仕様に基づき検 查経路ごとに結線状態, 絶縁状態の識別を行い, それ ぞれの経路について共振現象発生の有無を確認し，そ の回路の正常・異常の判定を行う.

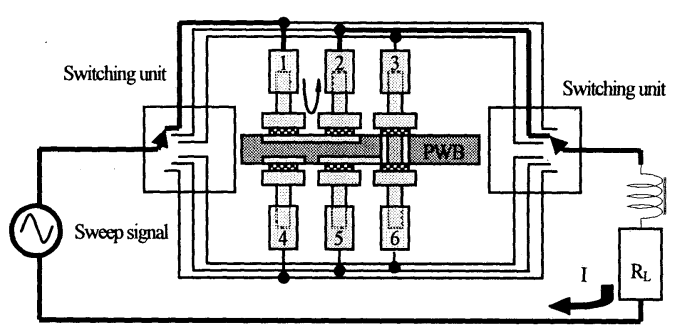

Fig.8 Inspection circuit in the case of normal connection

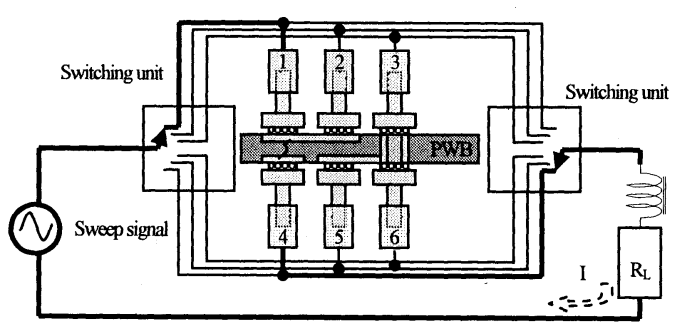

Fig.9 Inspection circuit in the case of short

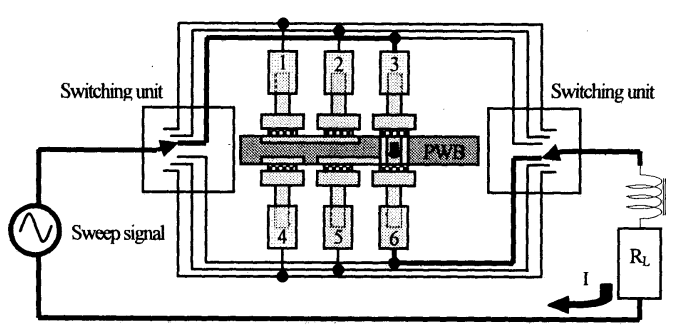

Fig.10 Inspection circuit in the case of through-hole

$4 \cdot 1$ 断線検査 (BGA Model) 図 11 は断線検査 の例を示す. 各記号は結線回路別の 2 電極間にスイー プ信号を印加したときの負荷抵抗両端の電圧をUSB コ

*両面酻袜反: double-side print wiring board (JS C5603-1993)

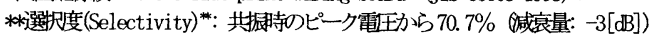
に低下寸る周波数带域を算出し, 周波数带或と共层堿数を定量化したもの. 一般的電皮の感度としても使われる。 
ンピュータの A/D ポートを介して測定した結果を示す. 結線回路( $、 \mathbf{\square}, \boldsymbol{\Delta} \cdots)$ の共振曲線はほぼ同じ軌跡を描 き, 断線 (異常) 回路(十)においては出力電圧に変化は 見られなかった.このことから, Pattern 面側電極・Ball 面側電極に接触させたプローブと BGA の配線によっ て構成されるコンデンサの合成静電容量が安定してい るものと思われる. BGA 上に配置された 16 組の断線 検査を行った結果 good:15, no good:1 となり, その際の 平均共振周波数 $\mathrm{f}_{\mathrm{r}}: 165[\mathrm{kHz}]$, 選択度(Selectivity) ${ }^{* *}: \mathrm{S}=7.75$ となった.ここで no good の回路は意図的に断線させた 回路を用いたものを使用した.

\section{4-2 短絡検查 (BGA Model) 図 12 は短絡検査} の例を示す. 各記号は絶縁回路別の 2 電極間にスイー プ信号を印加したときの負荷抵抗雨端の電圧を示す. 絶縁回路( $、 ， ， \boldsymbol{\Delta} \cdots)$ の出力電圧に変化は見られな

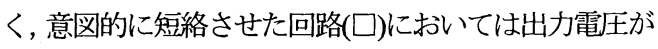
生じ，共振曲線を描いている. BGA 上に配置された 16 組の短絡検查を行った結果 good:15, no good:1 とな り, 意図的に短絡させた回路の共振周波数 fr: $150[\mathrm{kHz}]$, 選択度: $S=15.0$ となった。

\section{$4 \cdot 3$ 複合配線検查 (PWB Model) PWB は基板} 上の同一銅筞面に複数の電極が設けられた構造となっ ているため断線・短絡検查を混在されて行うことにな る. 図 13 はPWB の例を示す. ピンプローブはPWB 片面の電極に対応させ Insulator に固定し, あらかじめ 位置決めされた PWB を上下から挟み込む方式を取っ ている. 検査結果として, 設計上結線( 、, 口)されて いる 2 電極間は予測された共振曲線を描くが, 設計上 絶縁(の，、‥)されている配線においても低電圧の共 振現象が確認された. 絶縁回路間の共振現象は検査回 路内に浮遊する静電容量により PWB の配線以外をバ イパスして共振電流が生じているものと考えられる. PWB 上に配置された 7 組の断線検査を行った結果 Connection:2, Insulation: 5 となり, 結線回路における共 振周波数 $\mathrm{f}_{\mathrm{r}}: 142[\mathrm{kHz}]$, 選択度 $\mathrm{S}=10.6$, 絶縁経路にお ける共振周波数 $\mathrm{f}_{\mathrm{r}}$ : $146[\mathrm{kHz}]$, 選択度 $\mathrm{S}=7.1$ となった.

\section{5. 考 察}

(1)従来の静電容量型検査装置では, 配線間に生じる静 電容量を測定することによって, 断線・絶縁の検査が 行われている. 本研究で基礎実験を行った結果, 配線 間の静電容量は $1[\mathrm{pF}]$ 以下であり, また複数層の場合, 配線の交差状態によって $3[\mathrm{pF}]$ 程度を示すこともある. このように配線間の微弱な静電容量はばらつきが大き く, 結線状態の良否の判断は困難である. 本研究の配 線検査方法ではプローブ先端に高誘電体材料を装着す

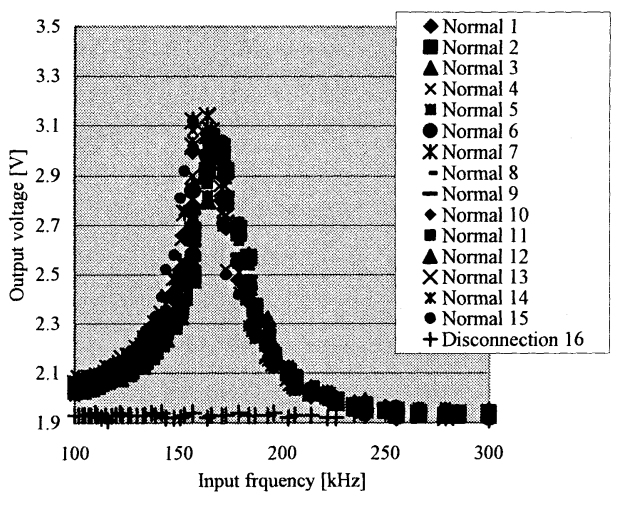

Fig.11 Inspection circuit in the case of normal connection for BGA

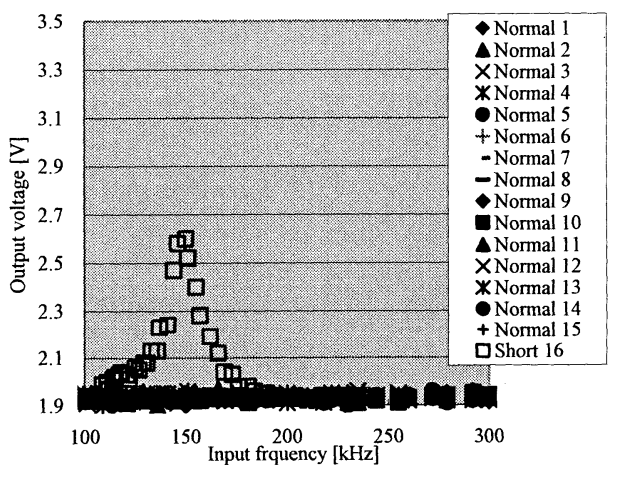

Fig.12 Inspection circuit in the case of short for BGA

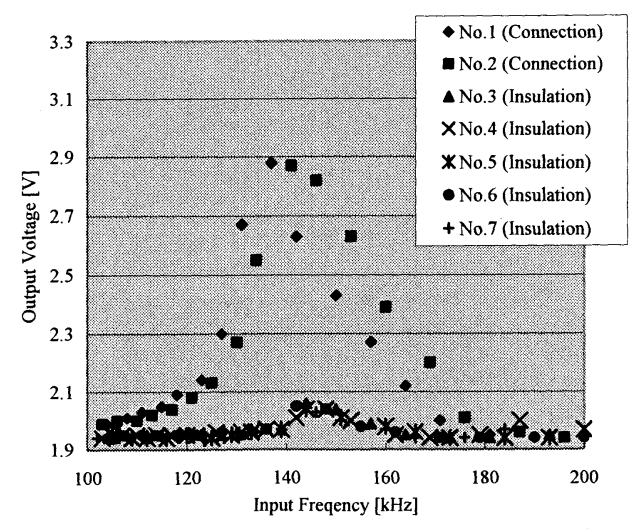

Fig.13 Inspection circuit in the case of normal connection with short for PWB. 
ることにより, 電極間の浮遊静電容量に比べ大きな静 電容量（30４0[pF]）を得ることにより共振特性の改善 をはかった. また検查回路の共振周波数を低く設定す ることにより，ノイズの影響を受けにくい周波数帯域 において直列共振回路方式による配線検查が可能とな った.

(2)多数電極の配線検查を行うためには配線を切り替え, 指定した回路に検査信号を入力する必要がある. 本研 究で使用したUSB コンピュータは市販されている H8 を搭載し，USBによってPC と通信を行っている. 市 販されているマイコン(MPU)では, PC との通信には特 別な知識が必要であるが, USB コンピュータにはVisual C++(MS)やC ++ Builder (Borland)用のポート制御プログ ラムがパッケージングされている.これにより, 高速 で切り替え信号を出力することが可能となり, A.M.P. と組み合わせることで高速回路切り替え（プローブ選 択）が実現できた。

\section{6. 結 言}

(1) 先端に高誘電体物質を装着した検査プローブを直 列共振回路の要素と見做した静電容量型プリント基板 検査システムの構築に成功した. 本システムを用いる ことにより, 従来通電式プローブの接触圧による電極 の破損と導通不良の問題が改善された. また, 小さい プローブを使用することによって BGA のようなプリ ント配線板にも対応できた。
(2)H8-3048 Micro processor unit を搭載した USB コンピ ュータとアナログマルチプレックサを用いることによ り, 高速回路切替えが可能となった.

(3)誘電体付プローブおよびその周辺の配線に伴う電 気的な寄生・浮遊静電容量の存在が明確となった.

\section{謝 辞}

本論文の作成に当り先行研究を行った、和久井健氏 (現: 日本発条), 傳田直史氏(現:長野県工業技術セン ター), 山川智史氏 (現: 東京海上日動システムズ(株)) の研究成果を活用させていただいた. プリント配線板 はユメックス(株), 誘電体材料は (株) 日本セラテック より提供していただいた.ここに各位,各社に対し深甚 なる謝意を表します。

\section{文 献}

(1) Denda, N., Yamakawa, T., Wakui, K., Satomi, T., Development of Printed Circuit Board's Inspection-system, Proceedings of JSME Annual Meeting, Vol.VI, (2003.8), pp. 219-220.

(2) Obana, Y., Present State and Trend of Printed Wiring Board, Journal of the Institute of Electrical Engineers of Japan, 105(9), (1985.9), pp. 831-857.

(3) Nidaira, Y., Inspection System of Printed Circuit Board, Electronics, 32(7), (1987.7), pp. 54-57, Ohmsha, Ltd.

(4) Ito, K., Technology Reader of Printed Wiring Board, (2000), Nikkan Kogyo Shimbun, Ltd. 